\section{NASA seeks 'fair exchange' of technical data}

[WASHINGTON] The US National Aeronautics and Space Agency (NASA) has launched a campaign to ensure that international research agencies which receive its technical reports at no charge reciprocate by sharing their own published data.

Most do this already, says Terese Ohnsorg of NASA's Science and Technical Information (STI) Office, which handles the exchanges. But some do not, and the agency is reluctant to see this situation continue.

Since the 1960s, NASA has traded technical information - mainly reports and conference proceedings generated by its scientists and contractors - with foreign aerospace agencies, private companies and universities.

Some 90 organizations in 27 countries are on the mailing list to receive the reports. The European Space Agency (ESA) and the Japanese space agency NASDA disseminate the information they receive to hundreds of other organizations. In return, the non-US space agencies are supposed to give their own reports to NASA.

The US space agency periodically looks at these reciprocal agreements to confirm that those who receive technical information are also providing it. "We don't expect that it will be exactly equal, but we expect a good-faith effort," says Ohnsorg.

The current review shows that some recipients have not been contributing their fair share. Ohnsorg plans to write to 15 of the worst offenders this week, asking them to increase their contributions. They could ultimately be removed from the distribution list if they fail to correct the imbalance.

At first ESA appeared to be one of the problem partners. "We realized there were things in the ESA database that weren't getting to us, and we couldn't figure out why that would be," says Ohnsorg.

But this turned out to be a misunderstanding. ESA thought NASA was not interested in certain kinds of information, such as reports on robotics and climate research. When NASA said it was interested, the problem was easily resolved.

That has led NASA to reconsider its guidelines on what kinds of material should be included in the exchanges. With modern computer search capabilities, says Ohnsorg, database managers can afford to err on the side of including rather than excluding information.

NASA's Langley Research Center, which administers the STI database, is forming an advisory group of scientists and engineers to establish guidelines on what kinds of information it should include.

Tony Reichhardt

\title{
Canada wins biotech boost of cancer vaccine project
}

[OTTAWA] Canadian researchers have won out over their French counterparts in a cancer vaccine development project that the Prime Minister, Jean Chrétien, calls "the largest biotechnology investment ever made in Canada".

Joint lobbying by Canadian politicians and scientists has persuaded the French parent company of Pasteur Mérieux Connaught Canada to invest up to $\mathrm{C} \$ 350$ million (US\$255 million) over 10 years in research to be carried out in Canada rather than France.

The Canadian federal government will invest $\mathrm{C} \$ 60$ million in the project, which aims to develop vaccines to combat eight forms of cancer that account for 66 per cent of cancer cases in Canada (bladder, lung, prostate, cervical, breast, ovarian, colorectal and melanoma). Repayment of the contribution will depend on sales, projected at as much as $\mathrm{C} \$ 10$ billion over 10 years.

Canada's lobbying success with JeanJacques Bertrand, president and chief executive officer of the parent company, Pasteur Mérieux Connaught (Rhône-Poulenc Group), resulted partly from the country's tax credit system. In Canada, research and development costs companies only 60 cents for every dollar spent, as against about 90 cents in France or the United States.

Unusually, Canada provides no direct subsidies, while in France this type of research could receive subsidies of up to 50 per cent. Canada’s C $\$ 60$ million investment in this project will be provided through the Technology Partnerships Program, set up by the industry department to create jobs through research in aerospace and biotechnology. Manley: 'result of

The project could partnership plan'. eventually create up to 300 jobs directly and employment for another 250 people in research centres, universities, hospitals and the private sector.

Those who had given their backing to the deal included Canada's three major research grants agencies. The industry minister, John Manley, called the project "a tangible result of this government's strategy for building an innovative economy through partnerships".

About 60 organizations across Canada are likely eventually to be involved. The main focus of the research will be tumour-associated antigens, peptide and carbohydrate technologies, adjuvants, immunomodulators and immunotargeting.

Heather Munroe-Blum, vice-president for research and technology transfer at the University of Toronto, calls the arrangement "a wonderful endorsement of the quality of research in Canada and particularly in the Toronto area."

DavidSpurgeon

US funds for ITER safe for one more year

[WASHINGTON] United States participation in the International Thermonuclear Experimental Reactor (ITER) project is secure for at least another year after the Clinton administration scotched a move in the Congress to end the collaboration (see Nature 388, 110; 1997).

According to administration officials, Federico Peña, the energy secretary, intervened personally last week to secure funding for ITER. Peña apparently persuaded Joseph McDade (Republican, Pennsylvania), chairman of the House of Representatives Energy and Water appropriations subcommittee, which funds energy research, and Vic Fazio (Democrat, California), its senior minority member, that the project should be fully funded.

The House subcommittee subsequently finalized a budget bill that would fund the fusion energy sciences programme at the administration's requested level of $\$ 225$ million. The Senate subcommittee went further, increasing fusion funding to $\$ 240$ million.

The bills proposed by both subcommittees would fund non-military science programmes at the Department of Energy at the level proposed by the Clinton administration in February (see Nature, 385, 569; 1997). High-energy physics, for example, would get $\$ 675$ million - the same as last year including \$35 million for the US contribution to the European Large Hadron Collider project.

But the Senate bill would provide an additional \$300 million for nuclear weapons research and maintenance, over and above the $\$ 4$ billion proposed by the Clinton administration. Senator Pete Domenici (Republican, New Mexico), chair of the Senate panel, said the money was needed to maintain a larger than expected nuclear weapons stockpile. Half of the proposed increase would go to the Sandia and Los Alamos laboratories in Domenici's home state.

Colin Macilwain 